\title{
ResearchOnline@JCU
}

This is the Accepted Version of a paper published in the Journal:

Fisheries Research

Disspain, Morgan C.F., Ulm, Sean, Draper, Neale, Newchurch, Jeffery, Fallon, Stewart, and Gillanders, Bronwyn M. (2018) Long-term archaeological and historical archives for mulloway, Argyrosomus japonicus, populations in eastern South Australia. Fisheries Research, 205. pp. 1-10

http://dx.doi.org/10.1016/j.fishres.2018.03.009

(C) 2015. This manuscript version is made available under the CC-BY-NC-ND 4.0 license http://creativecommons.org/licenses/by-nc-nd/4.0/

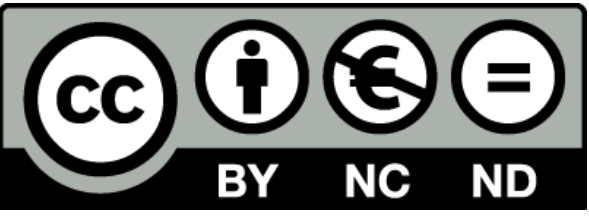




\section{Long-Term Archaeological and Historical Archives for Mulloway, Argyrosomus japonicus, Populations in Eastern South Australia}

Morgan C.F. Disspain ${ }^{\mathrm{a}, b^{*}}$, Sean Ulm ${ }^{\mathrm{c}, \mathrm{d}}$, Neale Draper ${ }^{\mathrm{e}, \mathrm{f}}$, Jeffery Newchurch ${ }^{\mathrm{g}}$, Stewart Fallon ${ }^{\mathrm{h}}$ and Bronwyn M. Gillanders ${ }^{\mathrm{a}}$

a Southern Seas Ecology Laboratories, School of Biological Sciences, University of Adelaide, SA 5005, Australia morgandisspain@gmail.com,bronwyn.gillanders@adelaide.edu.au

b Everick Heritage Consultants Pty Ltd, PO Box 200, Coffs Harbour, NSW 2450, Australia

c ARC Centre of Excellence for Australian Biodiversity and Heritage, James Cook University, PO Box 6811, Cairns, QLD 4870, Australia sean.ulm@jcu.edu.au

d College of Arts, Society and Education, James Cook University, PO Box 6811, Cairns, QLD 4870, Australia

e Neale Draper \& Associates Pty Ltd, PO Box 366, Prospect, SA 5082, Australia

Neale.Draper@ndaa.com.au

f College of Humanities, Arts and Social Sciences, Flinders University, GPO Box 2100, Adelaide, SA 5001, Australia

g Kaurna Nation Cultural Heritage Association, Warriparinga, Bedford Park SA 5042, Australia

jeffreynewchurch@hotmail.com

h Research School of Earth Sciences, Mills Road, The Australian National University, Canberra, ACT 2601, Australia stewart.fallon@anu.edu.au

* Corresponding author 


\begin{abstract}
Native fish populations have been strongly impacted by fishing, habitat alteration and the introduction of invasive species. Understanding the dynamics of native fish populations prior to commercial fishing can be problematic, but provides critical baseline data for fish conservation, rehabilitation and management. We combined fish size, age and growth data, as well as month of catch data, from archaeological fish otoliths (1670-1308 cal BP to 409-1 cal BP), historical anecdotes (AD 1871-2000), and contemporary data sources (AD 1984-2014) to examine changes to mulloway, Argyrosomus japonicus, populations in the waters of eastern South Australia. We found that the data from the three different sources - archaeological, historical and contemporary - corroborate each other in many aspects. The time of catch for all three datasets was seasonal, with increases evident during the summer months. No significant changes in fish length over time were evident over the time span of the three data sources. Given the impact that fishing in the region is regarded to have had, this may imply that while the maximum recorded sizes of the species have remained stable, the abundance of these large specimens may have declined.
\end{abstract}

\title{
Keywords
}

Otoliths; icthyoarchaeology; Kaurna; mound site; historical data; Trove

\section{Highlights}

- Mulloway archaeological, historical and contemporary data corroborate each other

- Month of catch data was highly seasonal, with increases during summer

- No significant changes in fish length observed over time

- Combining data sets to document fish population status through deep time addresses the shifting baseline issue 


\section{Introduction}

Anthropogenic impacts have profoundly altered aquatic ecosystems, yet attempting to return native fish stocks to 'baseline states' is difficult because the interpretation of a baseline status may change over time (Hobday 2011; Izzo and others 2016; Papworth and others 2009; Pauly 1995). The 'shifting baseline syndrome' refers to the concept that fish populations are measured against baselines identified by each successive generation of researchers, baselines which themselves may represent significant changes from even earlier states. There are problems associated with using only recent data when examining how fish populations have changed over time, as earlier changes will not be accounted for, resulting in the establishment of inappropriate reference points for evaluating losses from overfishing, or for identifying rehabilitation targets (Pauly 1995). By using multiple data sources from different times to examine populations, a clear picture of the changes can be developed, providing an improved picture of the impacts of anthropogenic and environmental influences. We tested this idea using a South Australian example (Argyrosomus japonicus) from a family of fishes that occurs worldwide and is often associated with estuaries, a characteristic that contributes to its status as 'vulnerable'.

Prehistoric fisheries data obtained from archaeological assemblages provide valuable snapshots of past fish populations that would otherwise be near-impossible to determine; as such, they are the best way to obtain prehistoric fisheries baseline data against which to compare more recent data (Butler 2010). Archaeological fish otoliths can be used to identify species, and estimate fish age, size, and season of death. Samples can be radiocarbon dated, assigning timeframes and allowing changes in fish population dynamics over time to be examined. Additionally, archaeological fish remains reveal information about the human inhabitants of an area, with fish otoliths specifically containing growth, trace element and isotopic data that can be used to investigate human behaviour and exploitation of their environment (Casteel 1976; Disspain and others 2011; Disspain and others 2016), as well as palaeoenvironmental conditions (Rowell and others 2005; Rowell and others 2008). However, archaeological data can have limitations. They are reflections of selective processes, such as cultural choices made by people, rather than direct representations of past fish populations (Reitz 2004), they undergo various taphonomic processes that impact preservation, and may represent populations already impacted by Indigenous fisheries (Mannino and Thomas 2002).

Historical records can be used to bridge icthyoarchaeological data with contemporary fisheries records. Historical data sources include archival fisheries reports, early fishing publications, newspaper articles, menus, artworks (Thurstan and others 2016; Thurstan and others 2015), archived 104 fish remains (Schaerlaekens and others 2011; Selleslagh and others 2016), early fisheries datasets (Fowler and Ling 2010), and oral histories, which can contain information relating to fish abundance, location of catch, fish size, catch rates, fishing methods and technologies, and species popularity. These sources can be problematic, with the possibility of being exaggerated or biased in other ways and interpreting them can be challenging. However, these data can provide useful information regarding past ecological systems, which fill the gap between prehistoric and modern times and address a range of conservation issues, significantly contributing to understanding current fishery status (e.g., Alleway and others 2016; Fowler and Ling 2010; Klaer 2001; Rosenberg and others 2005).

Contemporary fisheries reports contain detailed information about commercial, recreational and Indigenous fisheries species, including species biology, catch rates, catch and effort data, population structure (fish age and size), fishing methods and technologies, month and location of catches, analysis of performance indicators, and appraisals of the state of the species/fishery (Earl and Ward 2014; Flood and others 2014; 
Giri and Hall 2015). These data, although limited to commercially desirable species, provide a snapshot of current fish populations, which can be compared with historical and archaeological data, allowing investigations into changes over time and the impact of fishing. This information can also be contained in fisheries research or marine science publications, which may provide more detailed analyses and greater insight into the biology of species and the sustainability of stocks (Ferguson and others 2014; Griffiths and Hecht 1995).

Our aim was to obtain a long-term record of ecological 129 data on mulloway (Argyrosomus japonicus), also known locally by the trade name "butterfish", such that changes to populations of the species could be examined. We combined fish size, age and growth data from: archaeological fish otoliths from a mound site at Greenfields, South Australia (dating between 1670-1308 cal. BP and 409-1 cal. BP); historical anecdotes referring to mulloway fishing in southeast South Australia from the National Library of Australia's database, Trove (AD 1871-2000); and contemporary data sources reporting on the mulloway fisheries based in the Coorong area of South Australia (AD 1984-2014), to examine changes to A. japonicus, populations in the waters of eastern South Australia.

\section{Methods}

\subsection{Mulloway (Argyrosomus japonicus)}

The mulloway, Argyrosomus japonicus, is a large, predatory, teleost fish belonging to the sciaenid family. It is often associated with estuaries (Ferguson and others 2008; Griffiths 1996), and is distributed throughout the Indian and western Pacific Oceans. The species is fast growing and relatively long-lived, attaining a maximum age of ca 14641 years and size of $\sim 1800 \mathrm{~mm}$ (Ferguson and others 2014). Juveniles inhabit estuarine environments, with sexual maturity of female and male A. japonicus in South Australia occurring at 6 and 5 years respectively, after which time they migrate into marine waters (Ferguson and others 2014; Scott and others 1974). Adult mulloway typically aggregate around estuary mouths during the summer months, attracted by freshwater outflows and an abundance of food. Currently, this is when most of the commercial and recreational catch is taken in areas within South Australia; predominantly at the mouth of the River Murray (adults) and in the Coorong lagoons (juveniles) (Earl and Ward 2014; Giri and 154 Hall 2015; Jones and Doonan 2005). Mulloway are also targeted in the Port River-Barker Inlet by recreational fishers, primarily using rod and reel (Giri and Hall 2015). Measures, such as bag and minimum length limits, are in place in an attempt to sustainably manage stocks in South Australia; the minimum legal length for mulloway within the Coorong, including the channel of the River Murray mouth, is $46 \mathrm{~cm} \mathrm{TL}$, whereas within all South Australian marine waters, it is $75 \mathrm{~cm}$ (PIRSA 2015). Similarly to other sciaenid species, mulloway are vulnerable to anthropogenic impacts because of certain life history characteristics including estuarine association, high age/size at maturity and high maximum age (Ferguson and others 2014). Because of intensive harvesting since the arrival of Europeans in the area, populations of A. japonicas have been reported as overfished in eastern Australia (Silberschneider and others 2009) and vulnerable in South Australia (Ferguson and others 2014). There are noted differences in biological parameters between mulloway from different regions (Farmer 2008; Ferguson and others 2014; Silberschneider and Gray 2008). In particular, the mulloway population structure in South Australian may be more complicated than what current management efforts allow for (Barnes and Gillanders 2011). Such variation suggests that a greater emphasis on increasing the spatial and temporal breadth of sampling efforts is required in order to provide a comprehensive picture of mulloway structure and movement patterns, and to ensure appropriate management (Barnes and Gillanders 2011; Silberschneider and others 2009). 
The three data sources, archaeological, historical, and contemporary, were all sourced from locations within southeastern South Australia, enabling comparisons between the different datasets. The archaeological and contemporary sites are both coastal settings with estuarine rivers, each possessing similar environmental conditions where mulloway spawning and nurseries occur. The historical data were sourced from the southeastern coast of South Australia, from both estuarine and coastal catch data; some sites overlapped with the archaeological and contemporary data, but the historical data spanned a greater spatial scale. To compare data sources from three different geographic locations and time spans, we selected attributes to analyse that allowed direct comparisons (age, size, and growth), and were previously validated as providing accurate measurements (Disspain and others 2011; Ferguson and others 2011; Ferguson and others 2014). One disadvantage of this approach is that the geographical distribution of the different data sources may not allow the most accurate comparisons, because mulloway population structures can differ between locations (Barnes and Gillanders 2011). However, the archaeological data are compared with those from another archaeological site complex at the Coorong, South Australia (see Section 4), with similar patterns emerging, indicating that the methodology used is sound.

\subsection{The Study Region and Archaeological Site}

The eastern coast of South Australia encompasses Spencer Gulf, Gulf St Vincent, Yorke and Fleurieu Peninsulas, the Coorong, and the coastline continuing south to Nelson, just past the current border of Victoria (Figure 1). The Port River-Barker Inlet, the closest waterway to the Greenfields mound site, is the largest and most speciose estuary in the Gulf St Vincent, with 61 fish species identified (Gillanders and others 2008; Jackson and Jones 1999). The inlet has become severely degraded since the arrival of Europeans to the region in the 1800 s, with much of the formerly intertidal land drained for agricultural and industrial purposes, including salt evaporation ponds, industrial estates and large areas of landfill (Thomas 2010). Less impacted areas of the inlet are characterised by seagrass meadows, adjoining mudflats, mangrove woodlands and intertidal samphire wetlands (Thomas 2010); these environments are ideally suited as fish nursery areas supporting fisheries in Gulf St Vincent and beyond (Jones and others 1996). Areas of Port River-Barker Inlet are now aquatic reserves.

The Greenfields mound site is located on the flood plain of Dry Creek approximately $5 \mathrm{~km}$ from the current lower reaches and constructed wetlands of Barker Inlet, and approximately $10 \mathrm{~km}$ from the current coastline of the Gulf St Vincent. It is situated within the traditional lands of the Kaurna people. The site is a low mound (ca $80 \mathrm{~m}$ in diameter and up to $1 \mathrm{~m}$ high) composed of an accumulation of ash, charcoal, burnt heating stones from cooking ovens, stone tools, burials, food remains, decomposed plant material and earth. The site was excavated in 1992 after development uncovered cultural material. The excavation included the systematic removal of material from one area of the site within an arbitrary grid system of $1 \mathrm{~m} \times 1 \mathrm{~m}$ squares. It also involved sieving through disturbed sediment that had been excavated by earth-works during development of the site; Scrape 1 through to Scrape 7 indicate areas where the ground surface had been scraped by earthmoving machinery, exposing sub-surface cultural material, while other locations mentioned throughout the text - Front Garden, Office Garden, Side Garden, and Rubbish Pit - refer to places at the location to which the disturbed sediment had been relocated during earthworks. At the time of excavation, faunal remains were very well preserved and included skeletal parts of various species of bird, mammal, and fish; a large number of fish otoliths $(\mathrm{n}=522)$ were recovered during the salvage excavation, of which were identified as mulloway (Argyrosomus japonicus). The assemblage also contained otoliths from whiting (Sillaginodes punctatus, Sillago schomburgkii and Sillago flindersi) and snapper (Pagrus auratus). 


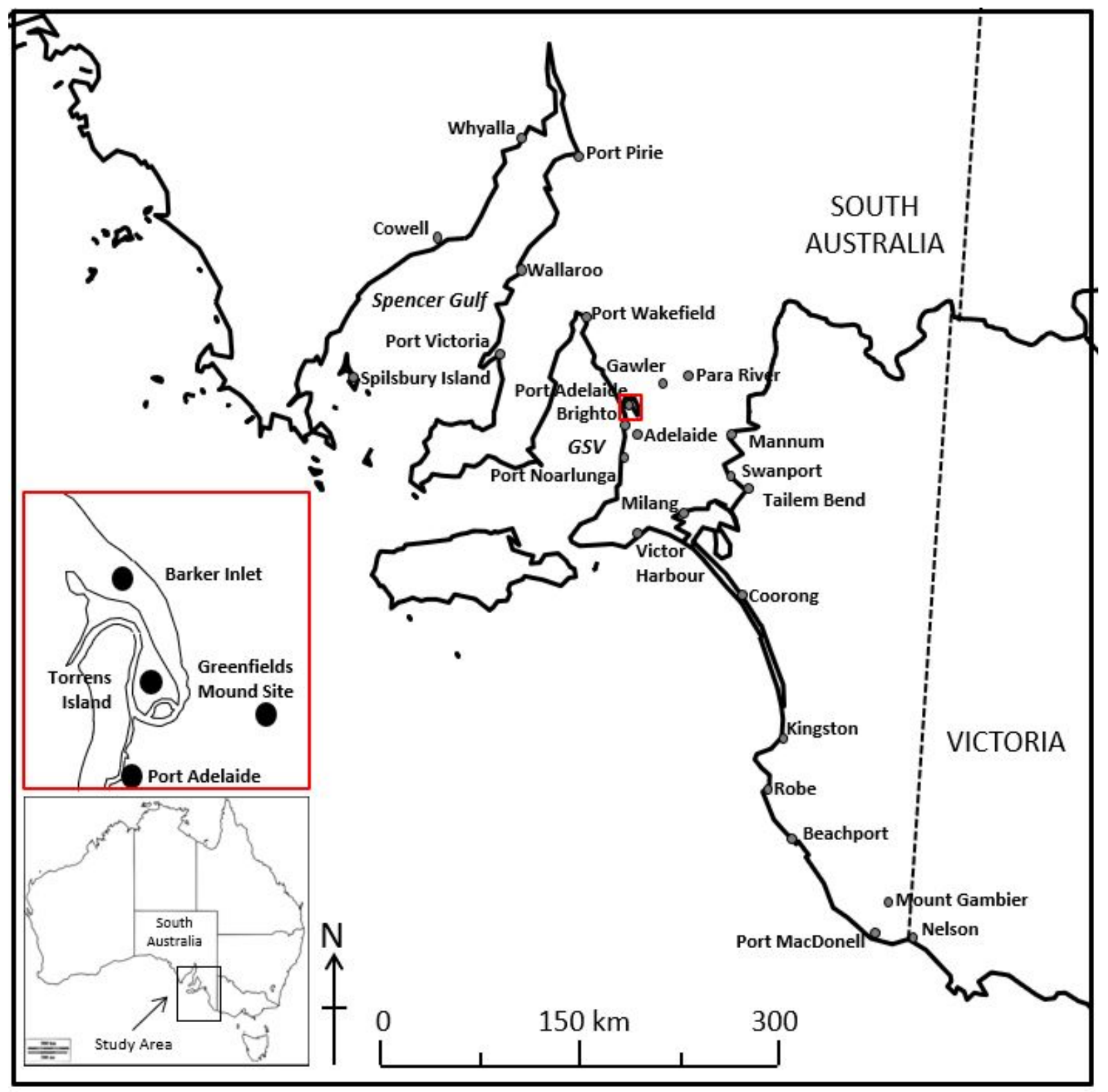

Figure 1. Map of eastern South Australia showing places mentioned in the text. 


\subsection{Archaeological Samples}

Nineteen mulloway otolith samples were radiocarbon dated at the ANTARES AMS facility at the Australian Nuclear Science and Technology Organisation ( $n=5$ ) (Fink and others 2004; Hua and others 2001), and the Radiocarbon Laboratory, Australian National University (=14) (ANU) (Fallon and others 2010). Sixteen of these dating samples came from known provenances within the site, while three dating samples (as well as the remaining 62 mulloway otoliths) came from disturbed areas of the site. Conventional radiocarbon ages were calibrated using the CALIB (v7.0.2) program (Stuiver and Reimer 1993), and the Marine13 calibration dataset (Reimer and others 2013) with a $\Delta \mathrm{R}$ value of $61 \pm 104$ as calculated for the nearby Gulf St Vincent (Ulm 2006). It is likely that the life histories of the fish included periods of fresh, marine and mixed environment habitation, $\delta^{13} \mathrm{C}$ values (Table 1 ) average 2.5 , which is close to the marine water value of $0 \pm 2$ reported by Stuiver and Polach (1977). However, if there was more freshwater influence, the reservoir age would likely be less, meaning that the calibrated ages here are likely a minimum age. Calibrated age ranges are reported at two-sigma.

Total fish length (TL), defined as the length from the tip of the snout to the extended longest caudal finray, was estimated from otolith weight. While most otoliths were very well preserved, some otoliths were broken and incomplete owing to post-depositional processes such as physical weathering and breakage; therefore, weights recorded for these specimens are minimum values only, and thus calculated fish lengths should be considered underestimates. Only those otoliths $>50 \% 256$ complete (i.e. large enough to be sectioned) were included in the size determination analysis; all otoliths were weighed to a resolution of $0.01 \mathrm{~g}$. The relationship between otolith weight and fish length was obtained from measurements of recently collected fish in which both otolith weight and total fish length were measured [Linear Regression: Ln(Total length $)=0.5611 \times \operatorname{Ln}\left(\right.$ Otolith wt) $+6.4761 ; \mathrm{r}^{2}=0.981 ; \mathrm{n}=968$ (Greg Ferguson, SARDI Aquatic Sciences, unpublished data)]. It is acknowledged that this population could have been impacted by exploitation, which possibly presents a source of bias. However, no otolith size/fish size data are available from populations precommercial fishing, so this possible bias is unavoidable.

For age determination, otoliths with a nucleus were rinsed using ultrapure water and left to air dry. They were embedded in resin, and placed in an oven at $54.5^{\circ} \mathrm{C}$ to harden overnight. Otoliths were then sectioned transversely through the nucleus using a Buehler Isomet Low Speed Saw (speed 2.5) equipped with twin diamond edge blades with spacers $(0.35 \pm 0.05 \mathrm{~mm})$. The sections were mounted on glass slides using crystal bond and labelled, but were not polished because of their fragility.

The visible annuli of each sectioned otolith were counted to estimate the individual age of each fish at the time of death. Sections were viewed under a Leica MZ16FA stereomicroscope illuminated by incidental light. Ages were estimated from counts of opaque zones along the posterior axis of the sulcus following Ferguson and others (2014). Two readers counted the annuli from the nucleus to the outer edge of each otolith. Where the two counts differed, the primary author made 279 a third count. The relative precision of the age estimates was calculated, using an index of the average percentage error (IAPE), as $5.88 \%$. The edge annulus was also recorded as being translucent or opaque, as this information indicates the season during which the fish was caught. The wide, translucent band is laid down during periods of fast growth during the warmer months, while the narrower, opaque bands are laid down during periods of slow growth during the cooler months. 
A von Bertalanffy growth curve was fitted to the age-length data for archaeological A. japonicus:

$L t=L_{\text {inf }}\left(1-\exp ^{-\mathrm{K}[t-\mathrm{t}]}\right)$

where $\mathrm{L}_{\text {inf }}$ is the mean asymptotic maximum length predicted by the equation, $K$ is

the growth coefficient and $t_{0}$ is the hypothetical age at which fish would have zero

length if growth had followed that predicted by the equation.

\subsection{Historical Data Collection}

We collected historical data from the National Library of Australia's database, Trove, conducting searches of the database using the keywords "mulloway OR butterfish". Searches were limited to South Australian newspaper records mentioning mulloway catches, and including fish size (length or weight), and location of catch. Records date from 1847 up to and including 1999, the date of the final available record on mulloway. Where a source mentioned a range of sizes, the maximum size was recorded. Anecdotes often detailed a range of sizes of individual fish caught when they reported on recreational catches, but when commercial catches were reported, most commonly they mentioned the maximum size in a haul (see supplementary material). Where lengths of fish were recorded in feet or inches, these measurements were converted to centimetres and used in statistical analyses; however, most of the anecdotes recorded only weights of fish (pounds). These weights were converted to kilograms, then fish TL was estimated using the logarithmic relationship between fish length (TL) and fish weight (Fish length TL $(\mathrm{cm})=21.303 * \ln ($ weight $(\mathrm{kg}))+47.41$ $\left(\mathrm{R}^{2}=0.976, \mathrm{n}=50\right)($ Disspain unpublished data).

\subsection{Contemporary Data}

Fisheries reports and publications on A. japonicus in South Australian waters were reviewed to obtain data on modern maximum and average weights and lengths, age and growth of the species.

\section{Results}

\subsection{Radiocarbon Dating}

The calibrated radiocarbon ages of the mulloway otoliths range between 1670-1308 cal BP and 409-1 cal. BP (Table 1). The dates are spread consistently over the period of occupation, with no distinctive clustering of dates. All otolith samples with known provenances were dated, as well as three samples from one of the disturbed areas of the site, the Office Garden. The ages of the three samples from the Office Garden were spread over the span of the site's occupation period, a reflection of the extent of the disturbance, and an indication that identifying patterns and changes over time in the ichthyofauna for which direct dates were not determined, within the disturbed areas of the site may be problematic. 
Table 1: AMS radiocarbon dates from the Greenfields archaeological mound site.

\begin{tabular}{|l|l|l|l|l|l|l|}
\hline $\begin{array}{c}\text { Otolith } \\
\text { Number }\end{array}$ & Square & \multicolumn{1}{|c|}{ Unit } & $\begin{array}{c}\text { Lab. } \\
\text { number }\end{array}$ & $\boldsymbol{\delta}^{\mathbf{1 3}} \mathbf{C}$ & $\begin{array}{c}\text { Conventional } \\
\text { Radiocarbon Age } \\
\text { (Years BP) }\end{array}$ & $\begin{array}{c}\text { Calibrated } \\
\text { Age (cal. } \\
\text { BP) }\end{array}$ \\
\hline GF377 & $\begin{array}{l}\text { Office } \\
\text { Garden }\end{array}$ & n/a & ANU-29930 & $1.0 \pm 0.8$ & $495 \pm 25$ & $\begin{array}{c}\text { unable to be } \\
\text { calibrated }\end{array}$ \\
\hline GF286 & Scrape 3 & F10 & ANU-29924 & $7.4 \pm 1.2$ & $660 \pm 30$ & $409-1$ \\
\hline GF101 & D8 & 1C & ANU-29917 & $-4.7 \pm 2.2$ & $680 \pm 45$ & $435-1$ \\
\hline GF121 & D9 & 1C & ANU-29933 & $5.0 \pm 1.2$ & $685 \pm 30$ & $436-1$ \\
\hline GF306 & Scrape 5 & A9 & ANU-29927 & $8.2 \pm 1.2$ & $685 \pm 30$ & $436-1$ \\
\hline GF112 & D9 & 1C & ANU-29918 & $6.6 \pm 1.1$ & $790 \pm 30$ & $502-246$ \\
\hline GF391 & $\begin{array}{l}\text { Office } \\
\text { Garden }\end{array}$ & n/a & $\begin{array}{l}\text { ANU- } \\
\text { 29932 }\end{array}$ & $7.6 \pm 1.2$ & $780 \pm 30$ & $504-231$ \\
\hline GF080 & C8 & 1D & OZO781 & $-2.0 \pm 0.1$ & $835 \pm 30$ & $520-273$ \\
\hline GF028 & B10 & 1C & ANU-29913 & $9.3 \pm 2.1$ & $850 \pm 40$ & $534-275$ \\
\hline GF301 & Scrape 3 & S9/E10 & ANU-29925 & $7.1 \pm 1.5$ & $975 \pm 35$ & $654-403$ \\
\hline GF007 & B7 & 1C & OZO779 & $-2.2 \pm 0.2$ & $1020 \pm 35$ & $668-449$ \\
\hline GF122 & D9 & 1D & ANU-29920 & $2.5 \pm 0.9$ & $1495 \pm 30$ & $1166-817$ \\
\hline GF379 & Office & n/a & ANU-29931 & $1.0 \pm 1.1$ & $1735 \pm 30$ & $1369-1057$ \\
\hline GF195 & H9 & 1B & OZO783 & $-2.4 \pm 0.2$ & $1780 \pm 40$ & $1460-1087$ \\
\hline GF196 & H9 & 1B & ANU-29921 & $1.6 \pm 1.2$ & $1805 \pm 30$ & $1478-1151$ \\
\hline GF302 & Scrape 3 & S9/E10 & ANU-29926 & $4.2 \pm 1.3$ & $1910 \pm 35$ & $1561-1256$ \\
\hline GF044 & C7 & 1B & ANU-29924 & $5.2 \pm 1.0$ & $1925 \pm 30$ & $1571-1269$ \\
\hline GF020 & B9 & 1A & OZO780 & $-2.3 \pm 0.1$ & $1975 \pm 40$ & $1647-1293$ \\
\hline GF108 & D9 & 1A & OZO782 & $-0.6 \pm 0.3$ & $1990 \pm 40$ & $1670-1308$ \\
\hline
\end{tabular}

\subsection{Archaeological Otolith Morphology}

Of the 81 A. japonicus otoliths identified from the archaeological assemblage, 73 were more than $50 \%$ intact, (complete $n=51$, broken tip $n=22$ ) enabling estimates of fish TL and age. The estimated fish TL, based on otolith weight, ranged from $501 \mathrm{~mm}$ to $1155 \mathrm{~mm}$. The estimated ages ranged from 4 to 15 years ( $\mathrm{n}=68)$, with the majority between 6 and 10 years old $(82 \%, n=56)$ (Figure 2). Fish were mostly caught during the warmer months, with 68 of the 69 samples analysed (98\%) possessing translucent edge increments. All data recorded for the otoliths are available online as supplementary information.

\subsection{Historical Data Collection}

A total of 257 historical sources (AD 1871-1999), which mentioned mulloway or butterfish, and provided information about the location of catch and individual size of the fish, were found (see online supplementary information). Of these, the highest number $(n=64,25 \%)$ were catches from the waters near Nelson, in the state's far south (now part of the state of Victoria). From the Coorong and Lower Lakes region, 54 (21.1\%) anecdotes were recorded, with quotes such as the following

Large Haul of Fish near Milang; MILANG. March 14. A big school of mulloway was noticed in the vicinity of the Milang Jetty on Friday. Fishermen had never seen big fish so close to the shore before, and were at first sceptical; but quickly realised that something extraordinary was apparent, and nets were set. Large sprays could be seen from the shore and the sight attracted 
many towns' people. The fishermen worked at high pressure for four hours, and the catch was estimated at many tons. Some of the fish weighed from 60 to $70 \mathrm{lb}$. Fish of that size have never been caught in great numbers here before (The Advertiser 16 March 1936).

The Port Adelaide ( $\mathrm{n}=41,16 \%)$ and Victor Harbour $(\mathrm{n}=37,14.5 \%)$ areas had the next highest numbers of anecdotes (Table 2), while Barker Inlet - within the Port Adelaide area - was mentioned once in 1954, referred to as 'the back of Torrens Island'.

Further confirmation has been received of mulloway taken at the back of Torrens Island. One catch consisted of eight mulloway of seven to 15 pounds. The location was between the old cattle station jetty and the red post at the cutting (Hook and Line, The Mail, 3 April 1954).

The maximum individual size of the fish ranged from $2.5 \mathrm{lb}$ (equivalent to $1.13 \mathrm{~kg}$ and $500 \mathrm{~mm} \mathrm{TL}$ ) on 23 April 1953 at the Glenelg River, Nelson to $46.2 \mathrm{~kg}$ (equivalent to $102 \mathrm{lbs}$ and $1290 \mathrm{~mm} \mathrm{TL}$ ) from the 22 October 1998 at Goolwa. Although the size range of fish from historic sources generally spanned the range of sizes found from archaeological middens, there was a greater frequency of larger fish from historical sources presumably reflecting the approach used whereby the largest fish mentioned was recorded, or the fact that many recreational fishers target large 'trophy' fish (Figure 2). Despite the wide range of sizes recorded, no significant change over time was evident within the time span of the historical anecdotes (Figure 3). Few small individuals were recorded from 1870 to 1890 (Figure 3); this could be because larger sizes were more regularly captured, so anything below a substantial size (in this case $1000 \mathrm{~mm}$ TL) was not worth reporting in the newspaper. The numbers of small individuals decreased from 1960 to 2000 (Figure 3); this may be evidence of tighter fishing regulations and introduction of size-limits, or may reflect the increasing sensationalization of news reporting - perhaps moderately-sized fish catches were no longer seen as something worth reporting in the later $20^{\text {th }}$ century.

The highest percentage of historical anecdotes were recorded during the warmer months of the year, with $37 \%$ of all anecdotes recorded in February and March, at the end of the Southern Hemisphere summer (Figure 4). The lowest number of anecdotes was recorded in September, at the start of spring. 
Table 2: Locations mentioned in historical anecdotes from South Australian newspaper records (18731999) available on Trove. See Figure 1 for a map of the locations.

\begin{tabular}{|l|c|c|}
\hline \multicolumn{1}{|c|}{ Location } & Frequency & \% \\
\hline Nelson & 64 & 25.0 \\
\hline $\begin{array}{l}\text { Coorong (Hindmarsh Island, Goolwa, Lower Lakes, Murray Mouth, Pelican Point, } \\
\text { Point Sturt, Poltalloch, Ram Island) }\end{array}$ & 54 & 21.1 \\
\hline $\begin{array}{l}\text { Port Adelaide (Outer Harbour, Osborne Wharf, Torrens Island, Largs Bay, } \\
\text { Semaphore, Grange Jetty) }\end{array}$ & 41 & 16.0 \\
\hline $\begin{array}{l}\text { Victor Harbour (Granite Island, Encounter Bay, Waitpinga, Port Elliot, Horseshoe } \\
\text { Bay, Basham Beach, Middleton, Chiton Rocks) }\end{array}$ & 37 & 14.5 \\
\hline Fleurieu Peninsula (Port Noarlunga, Onkaparinga River, Sellicks Beach, Port & 15 & 5.9 \\
Willunga) & & \\
\hline Milang & 4 & 1.6 \\
\hline Port MacDonell (Blackfellows Caves, Cape Douglas) & 4 & 1.6 \\
\hline Port Pirie/Port Germein & 4 & 1.6 \\
\hline Beachport & 3 & 1.2 \\
\hline Kingston & 3 & 1.2 \\
\hline Brighton/Seacliff & 3 & 1.2 \\
\hline Robe incl. Botswain Point & 3 & 1.2 \\
\hline Adelaide & 2 & 0.8 \\
\hline Cowell & 2 & 0.8 \\
\hline Gawler & 2 & 0.8 \\
\hline Mount Gambier & 2 & 0.8 \\
\hline Port Wakefield & 2 & 0.8 \\
\hline Swanport & 2 & 0.8 \\
\hline Wallaroo & 2 & 0.8 \\
\hline Gulf (near Whyalla) & 1 & 0.4 \\
\hline Mannum & 1 & 0.4 \\
\hline Para River, South of Tanunda & 1 & 0.4 \\
\hline Port Victoria & 1 & 0.4 \\
\hline Spilsbury Island & 1 & 0.4 \\
\hline Tailem Bend & 256 & 0.4 \\
\hline West Coast & & 0.4 \\
\hline Total & 1 & \\
\hline & 2 & \\
\hline
\end{tabular}




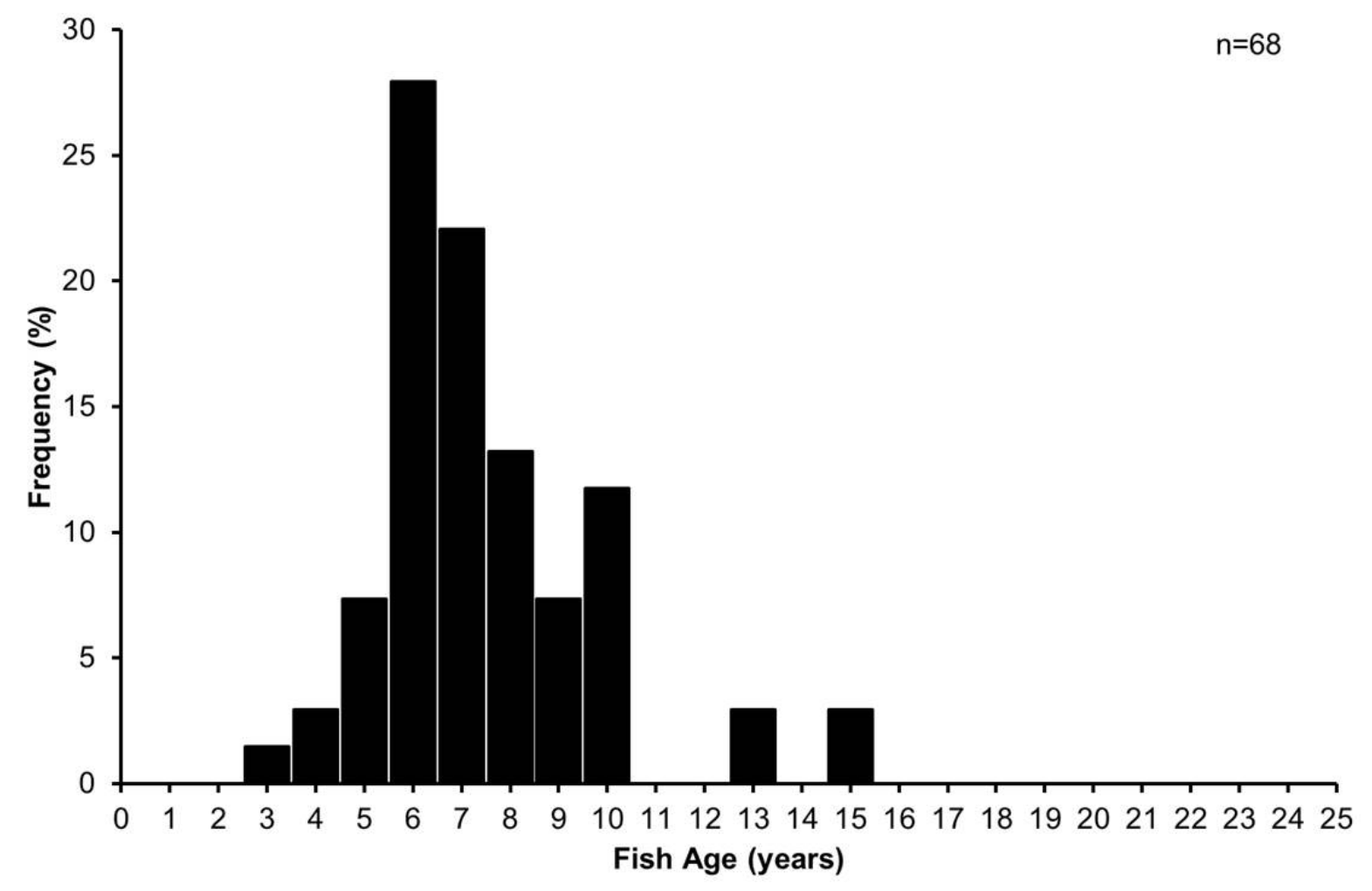

Figure 2a.

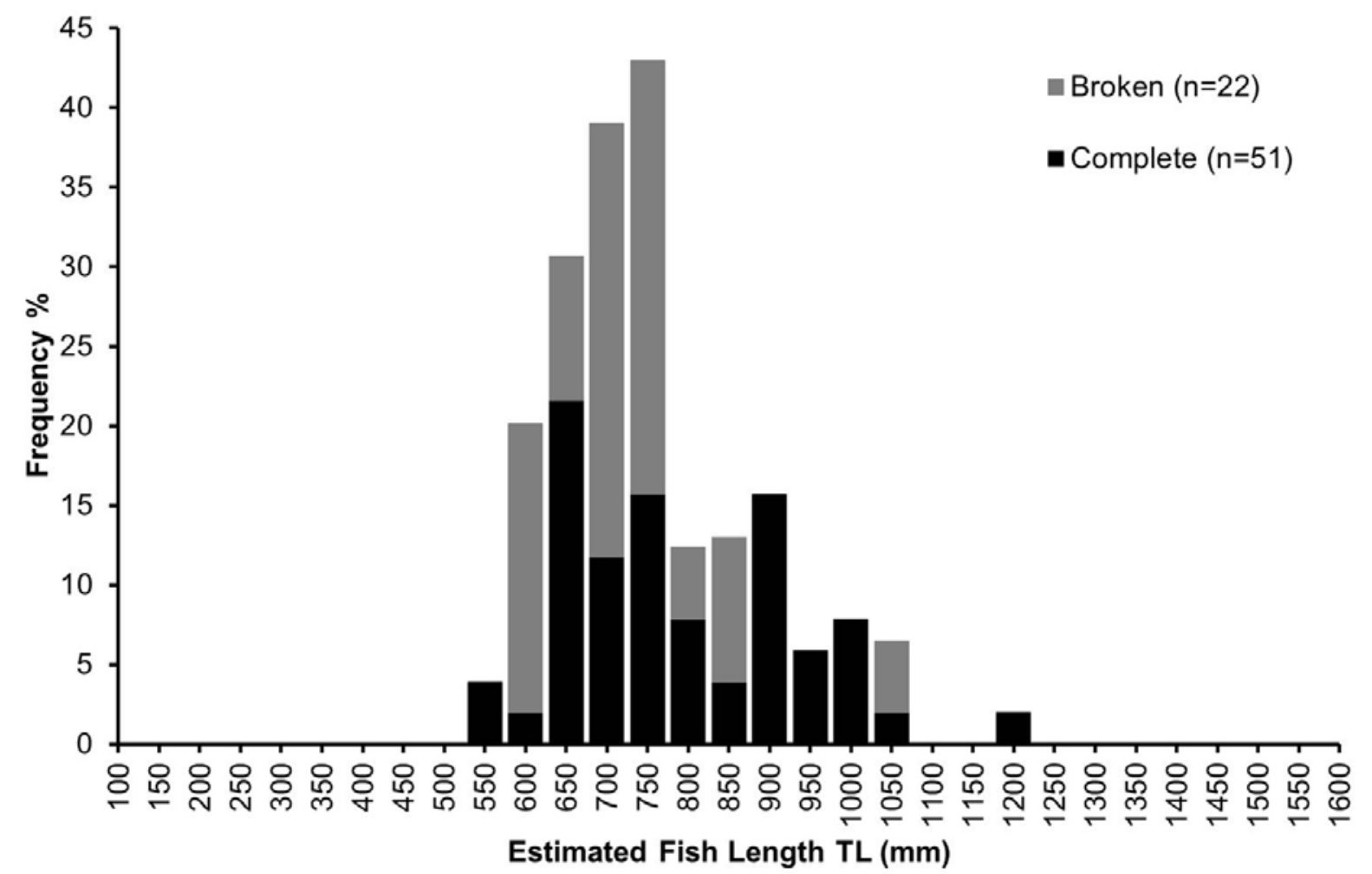

Figure 2b. 


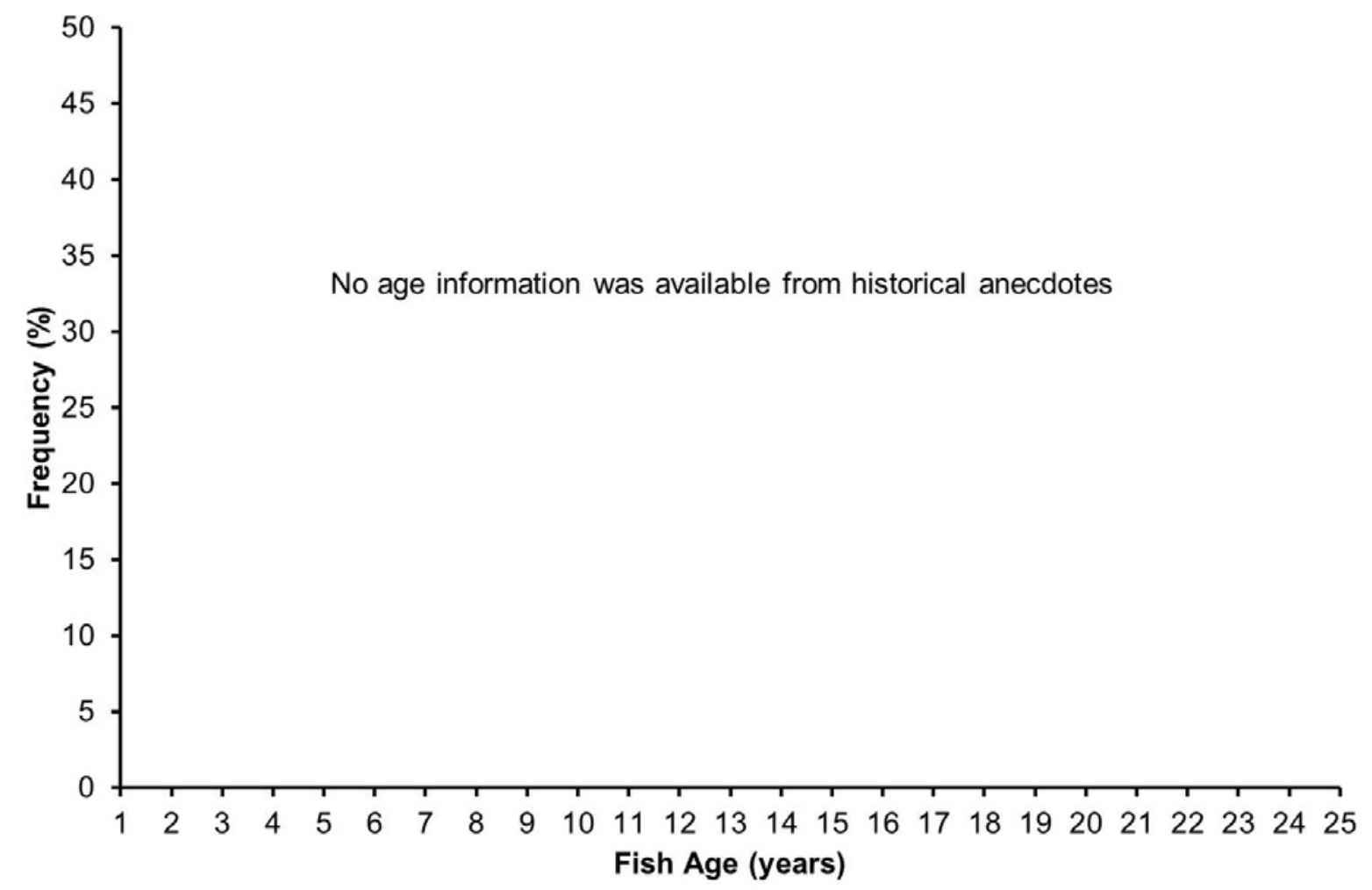

Figure 2c.

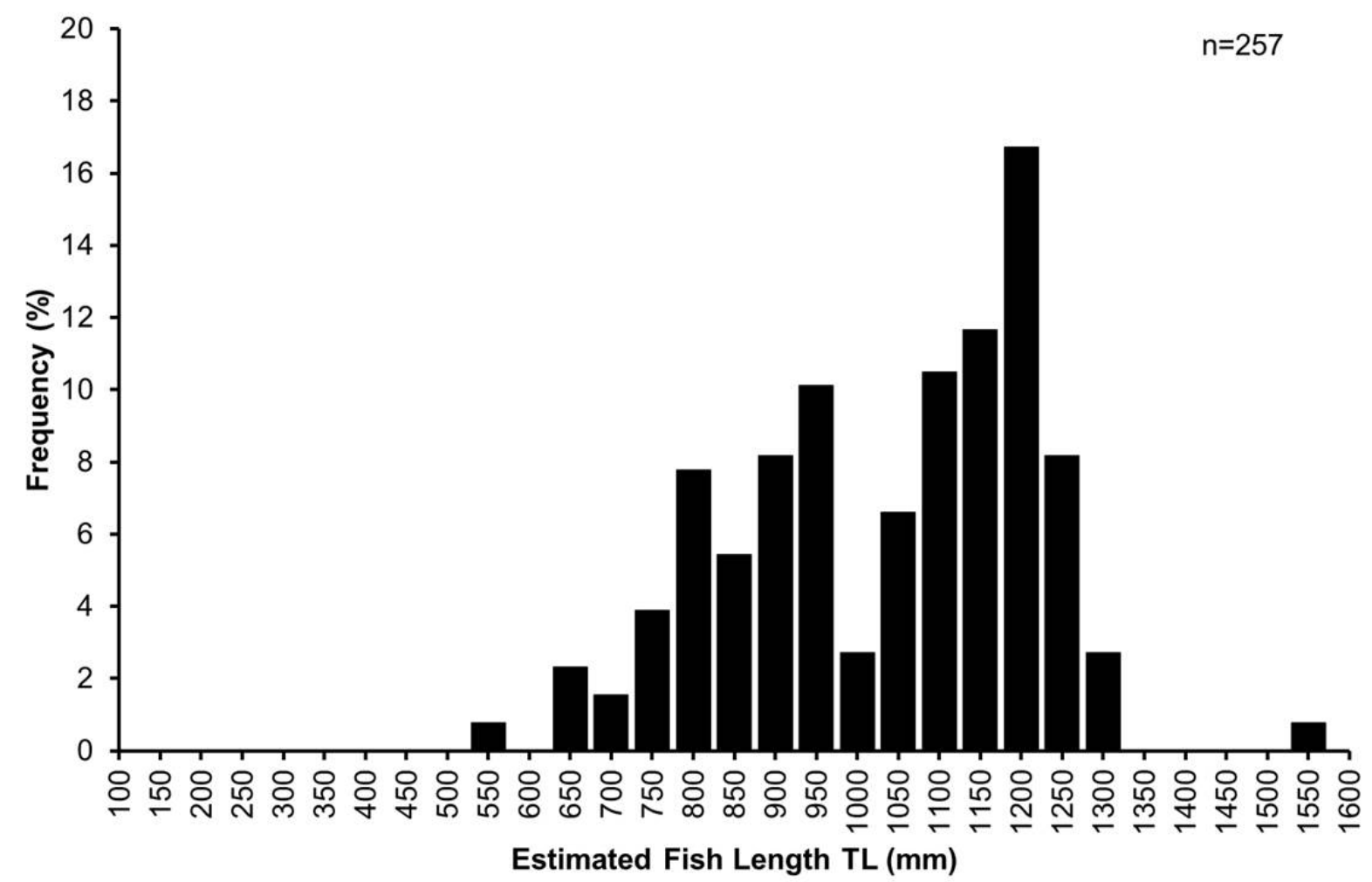

Figure 2d. 


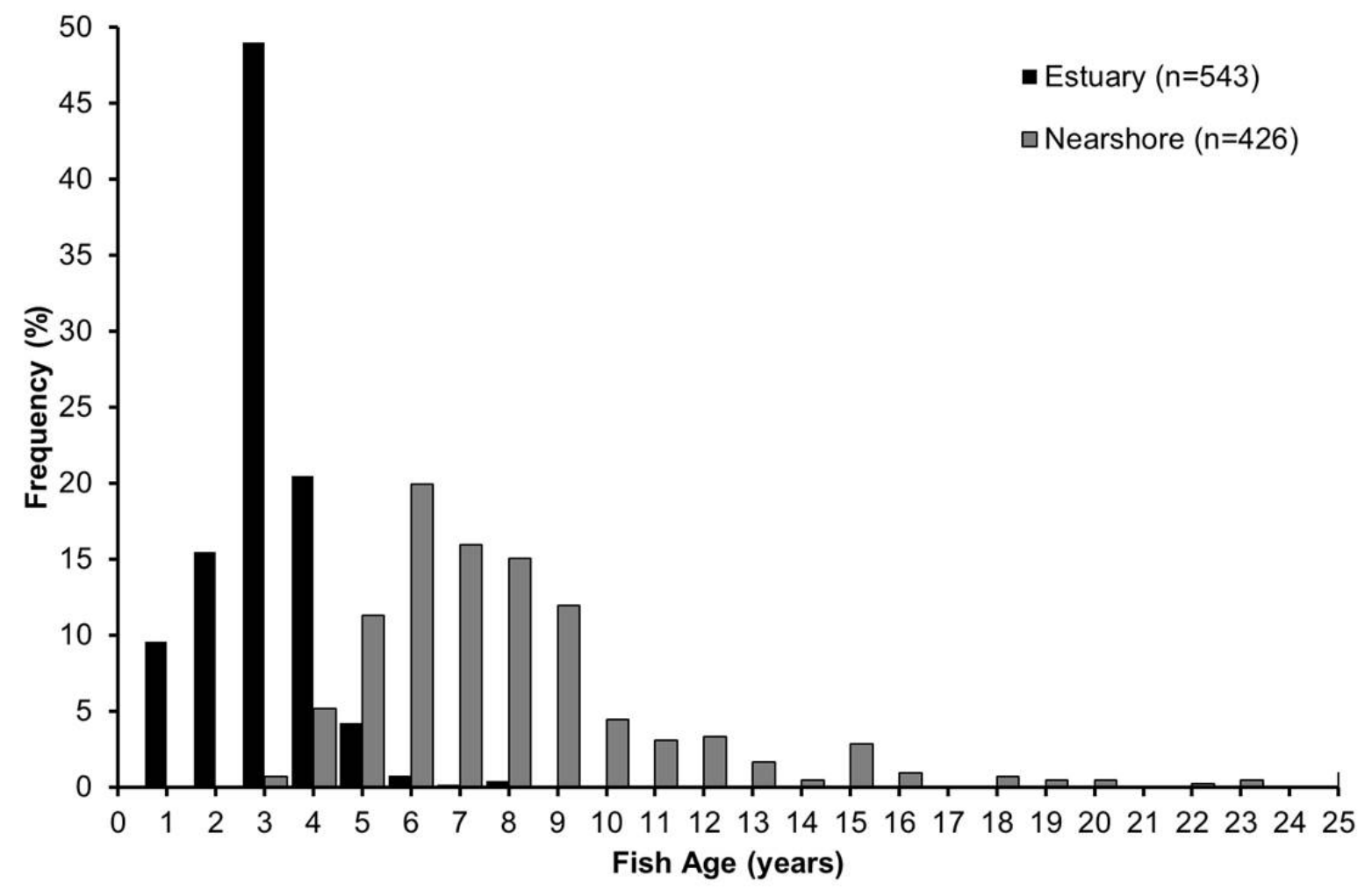

Figure 2e.

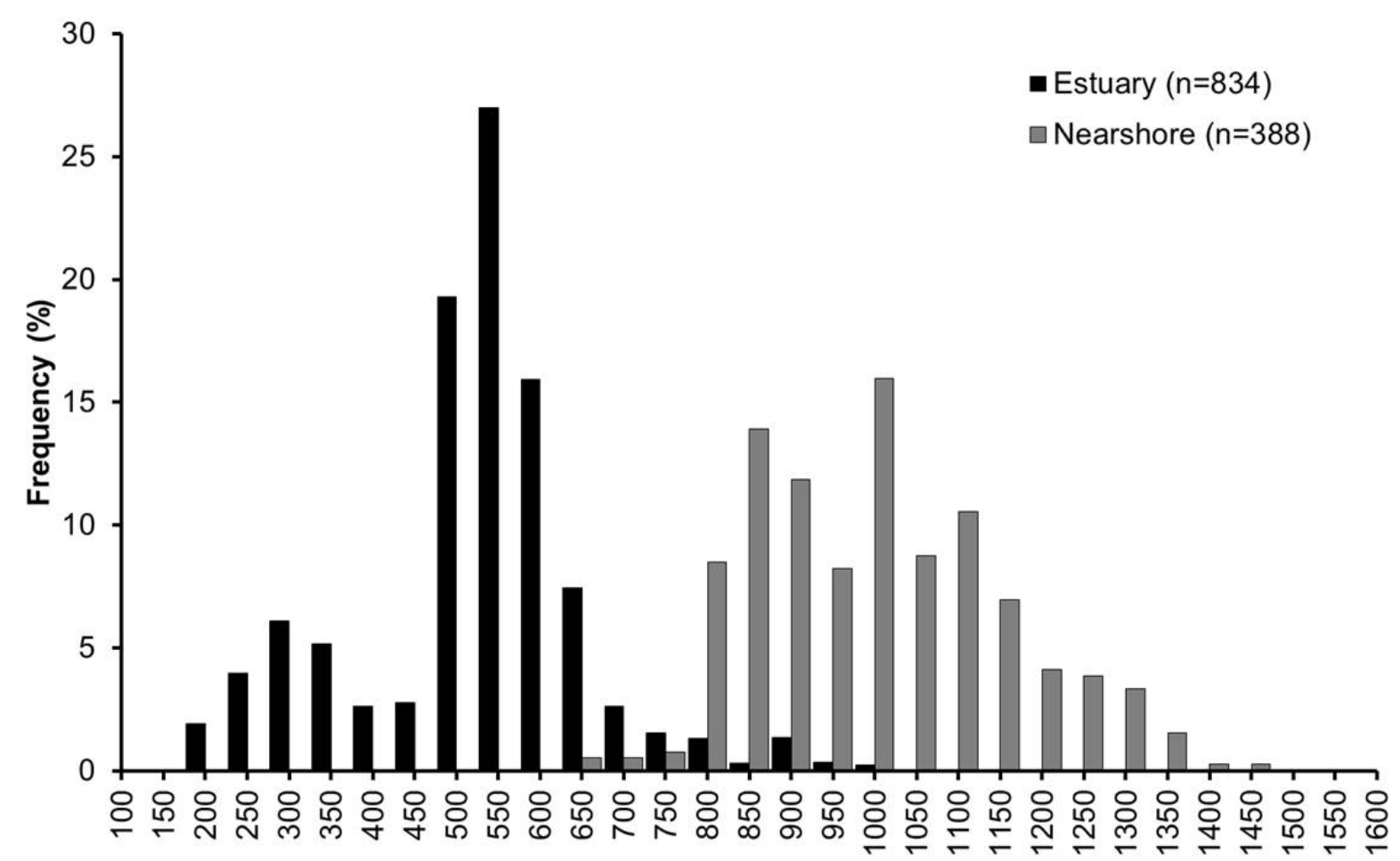

Fish TL (mm)

Figure 2f. 
Figure 2: Age (left) and length (right) frequency plots for mulloway based on (a and b) the otoliths from the Greenfields mound site, South Australia, (c and d) fish sizes mentioned in historical anecdotes in South Australian newspapers available in Trove (1873-1999), and (e and f) fish age and size as compiled from modern fisheries reports (Earl and Ward 2014). Modern fisheries data originates from the following years: Age and TL (LCF) 2000/2001, 2002/2003, 2013/2014; (MSF) 2000/2001, 2001/2002, 2009/2010 (no length data), 2010/2011 (no length data), 2011/2012, 2012/2013 (no age data), 2013/2014, 2014/2015 (no length data). Recreational and commercial catch data reported in Earl and Ward (2014) have been combined. Note differing values on the $y$ axes. Data are from two key fisheries in South Australia: LCF, Lakes and Coorong fishery data; MSF, marine scalefish fishery data. 


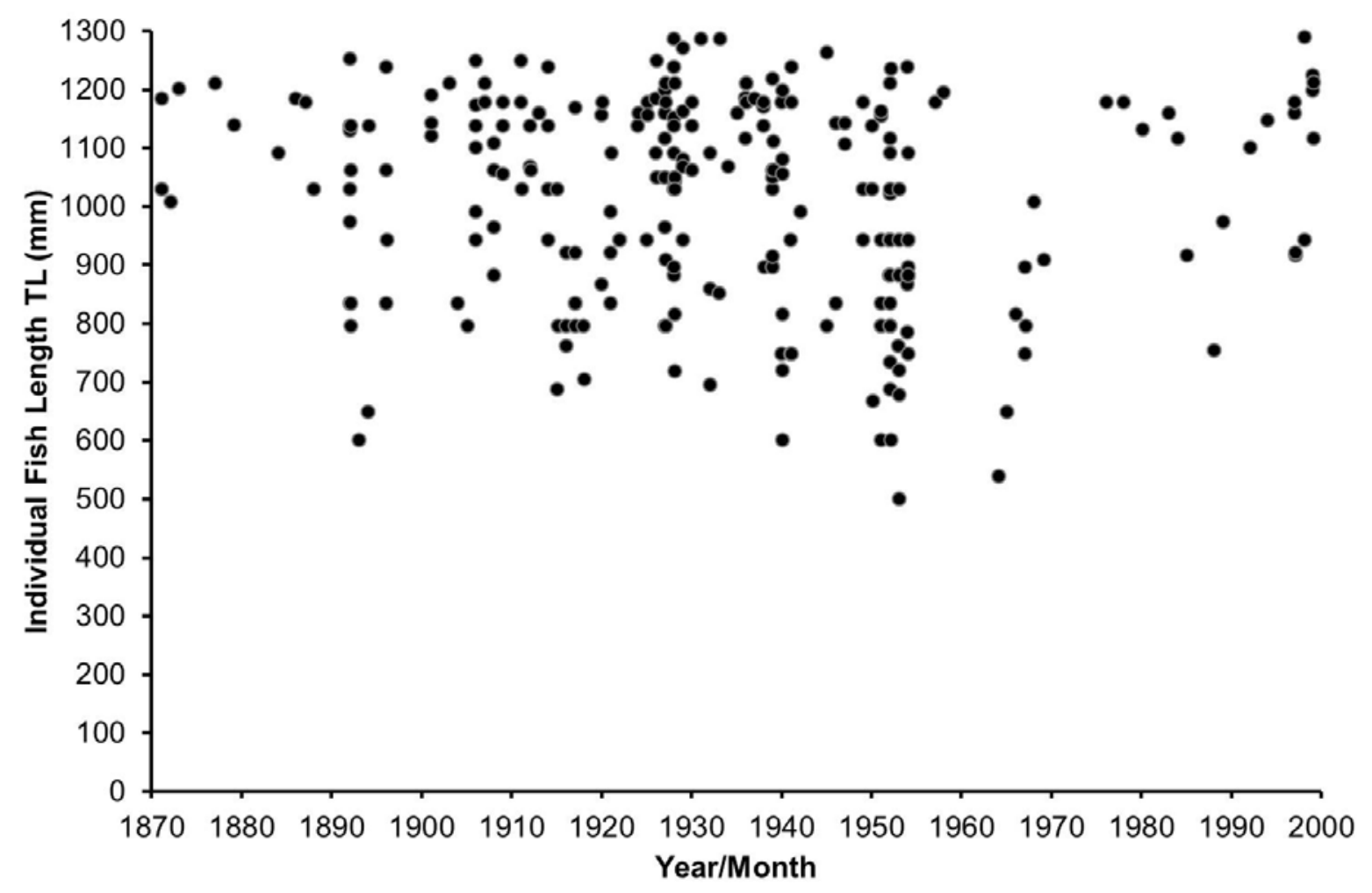

Figure 3. Individual Argyrosomus japonicus TL (cm) over time from 1873-1999 in eastern South Australia based on historical anecdotes from newspaper records available on Trove. The first four digits of the $\mathrm{X}$-axis labels refer to the year of catch, and the last two digits refer to the month of catch.

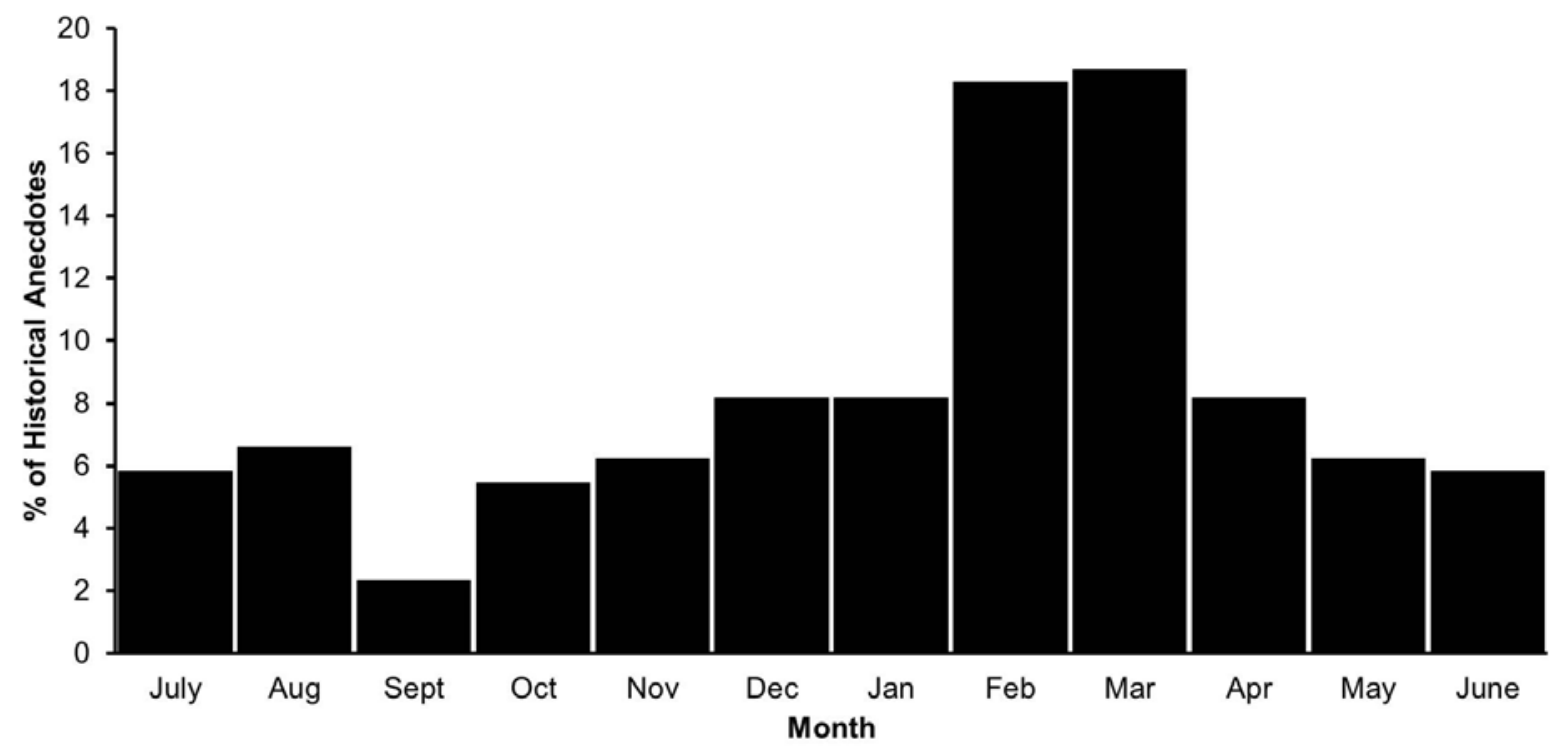

Figure 4. Month of catch of Argyrosomus japonicus (1873-1999) in eastern South Australia based on historical anecdotes from newspaper records available on Trove, expressed as a percentage of total number of anecdotes. 


\subsection{Contemporary Fisheries Data}

Fisheries reports provide commercial and recreational catch data from 1984 to 2014 including total annual catches, catch and effort, gear type, average monthly catches, and population size and age structure for both the Lakes and Coorong Fishery (LCF) and the Marine Scalefish Fishery (MSF) (Earl and Ward 2014; Ferguson and Ward 2003; Giri and Hall 2015). The catch data suggest that, while the most recently reported total annual catches (2013/2014) of $68.3 \mathrm{t}$ (LCF) and $1.1 \mathrm{t}$ (MSF) have decreased from previous years, this is a result of a decrease in fishing effort, rather than a decline in fishable biomass (Earl and Ward 2014).

Age structures from catches within the Coorong estuary over the last 15 years range from 1 year to 8 years, but are dominated by 3 year olds (Figure 2e). Nearshore populations in eastern South Australia ranged in age from 4 to 23 years, with most fish aged less than 10 years (Figure 2e).

Within the Coorong estuary, size structures ranged from $150 \mathrm{~mm}$ to $1000 \mathrm{~mm}$, but were dominated by fish between $450 \mathrm{~mm}$ and $650 \mathrm{~mm}$ (Figure2f). In the nearshore marine environment the size structures range from $650 \mathrm{~mm}$ to $1500 \mathrm{~mm}$ (Figure 2f), with a modal size of approximately $1000 \mathrm{~mm}$; fish >1200 mm were rarely recorded (Earl and Ward 2014; Ferguson and others 2014).

Within both the LCF and the MSF, higher monthly commercial catches between 1984/85 and 2013/14 occurred in summer (Figure 5). December and January had the highest catches for the LCF, with the lowest in August. On average, $68 \%$ of the annual catch within the LCF was taken from November to March. Within the MSF, the catches were also seasonal, with on average, $42 \%$ of the annual catch taken from November to February. Catches in the MSF were highest in December/January as in the LCF, and are lowest in September (Ferguson and others 2014).

\section{Discussion}

Trends in fishery data for A. japonicus from three 429 sources representing different periods (archaeological, historical, and contemporary) were generally similar. Using multiple data sources is useful because it extends the period over which changes can be investigated. However, it is important to recognise that the different datasets also have limitations when interpreting population parameters: archaeological otolith samples may be abraded, resulting in underestimates of fish TL; estimated lengths using otolith wt $\sim \mathrm{TL}$ relationship generated from recent data does not take into account potential effects of fishing; historical fish lengths and weights may be biased upwards due to this species being a "trophy/icon" species and our methodological focus on the largest fish caught; and contemporary data may be impacted by human pressures.

The range of sizes recorded from the contemporary data (150-200 $\mathrm{mm}$ to $1450-1500 \mathrm{~mm}$ ) was broader than those from the historical $(500-550 \mathrm{~mm}$ to $1500-1550 \mathrm{~mm}$ ) and archaeological (500-550 $\mathrm{mm}$ to $1150-1200$ $\mathrm{mm}$ ) data, although these latter two data sources may be biased because larger fish were targeted. Internationally, A. japonicus has been recorded at a maximum TL of $1800 \mathrm{~mm}$ and weight of $75 \mathrm{~kg}$ (South Africa, Griffiths 1996), while in Australia, individuals up to $1690 \mathrm{~mm}$ TL have been recorded (Silberschneider and others 2009). The smallest fish came from the contemporary data, and largest from the historical anecdotes. While most fish from the archaeological site were estimated to be between $550 \mathrm{~mm}$ and 
$800 \mathrm{~mm} \mathrm{TL}$, the size of the fish in the historical anecdotes were typically larger than this size range. Contemporary fish from the LCF were generally smaller than this range, while those from the MSF were generally larger than this range, which can be attributed to the presence of juvenile or adult fish in their respective environments. These differences are likely due to the nature of the data rather than major changes in the populations over time. The sizes estimated from the archaeological otoliths are minimum estimates owing to taphonomic processes such as breakage or weathering. Furthermore, the analysis of a small number of fish otoliths from one site may not represent the entire fish population of a region (Carder and Crock 2012) - a broader spatial examination would be beneficial in gaining a more comprehensive view (see below). The lengths recorded in the historical sources are likely the larger individuals as ordinary events do not usually gain media attention; as such, the historical anecdotes may be biased towards larger fish. Additionally, where a range of sizes was reported in the records, the largest were used for analysis. The contemporary data will be influenced by the methods used to catch the fish, as well as minimum catch sizes. Fishers operating in the Coorong use mainly large-mesh gill nets (115-150 mm mesh), while the MSF fishers use gill nets ( $>150 \mathrm{~mm}$ mesh size targeting larger, older fish), haul nets, and rod and lines to target mulloway (Earl and Ward 2014).

While there were no changes in fish length from historical anecdotes spanning 1871 to the end of 1999, this does not necessarily mean that the abundance of large fish has not changed. It is difficult to derive estimates of abundance from historical sources, as few records record total numbers caught. Many of the historical anecdotes from the early 1900s onwards discussed the scarcity of mulloway compared with earlier years and expressed concerns at the construction of weirs within the river (see supplementary data). While the historical data imply that the size structures of the species have remained stable, other characteristics, such as growth or abundance may have been affected.

The von Bertalanffy growth curve indicates that the asymptotic size $\left(\mathrm{L}_{\text {inf }}\right)$ for archaeological A. japonicus was $1577 \mathrm{~mm}$ TL and growth rate $(K)$ was $0.0548 \mathrm{y}^{-1}$ (Figure 6). The von Bertalanffy growth curves for the modern (Ferguson and others 2014) and archaeological samples suggested that fish present in the archaeological assemblage grew at a slower rate $\left(\mathrm{K}=0.0548 \mathrm{y}^{-1}\right.$ and $0.136 \mathrm{y}^{-1}$ for archaeological and contemporary fish respectively), but to a larger asymptotic size (add similar to $\mathrm{K}$ above) than their modern counterparts. The lack of young and old fish in the archaeological assemblage possibly means that the $t_{0}$ value is unrealistic, therefore comparisons of $t_{0}$ have not been made. Reduced $\mathrm{L}_{\text {inf }}$ could be a result of fishing, changes in population density or habitat quality, but determining the cause of such differences is difficult, with numerous factors such as data source and collection methods, species ecology, environmental change, and cultural behaviour also having an impact (Butler 2010). In addition, populations usually experience some degree of size and age alteration that reflects the targeting of larger, older individuals, with some species more susceptible to long term impacts, based on their ecological characteristics (Berkeley and others 2004; Fowler and Ling 2010). Growth overfishing alone does not always affect the ability of a population to replenish itself, but can lead to recruitment overfishing by reducing egg production (Fowler and Ling 2010; Silberschneider and others 2009).

The catch data for all three datasets showed a seasonal pattern, with an increase in mulloway catches during the summer months. This is likely due to the ecology of the species, with adults migrating closer to the shore during the warmer months to spawn and take advantage of the abundance of food produced by freshwater outflows from river mouths (Ferguson and others 2014). It may also be a reflection of the weather conditions and the ease with which the fishing grounds can/could be accessed. The majority of the fish from the 
archaeological and contemporary MSF assemblages were older than 5/6 years (the age at which the species migrates to marine environments from within the estuary (Ferguson and others 2014), and both possess similar age structures (Figure 2), albeit with the archaeological assemblage having a lower maximum age (archaeological $=15$ years, modern $\mathrm{MSF}=23$ years). This suggests that the majority of the fish from the archaeological site were likely caught in a nearshore environment, as opposed to in the nearby estuary. These ages are much less than the maximum recorded age of A. japonicus at 42 years in South Africa (Griffiths and Hecht 1995), and 41 years in Australia (Ferguson and others 2014); fish that have attained these maximum ages are rare, and lower maximum ages have also been recorded of 24 years (Silberschneider and others 2009) and 32 years (Farmer 2008) in New South Wales and Western Australia respectively.

The data acquired from the A. japonicus otolith assemblage from the Greenfields archaeological site are comparable to those from a midden site further south at Long Point in the Coorong, which was used by Ngarrindjeri people from 2500 cal BP through to modern times (Disspain and others 2011; Disspain and others 2017). This Coorong site contained only 20 A. japonicus otoliths; the majority of the fish at both archaeological sites, Greenfields, and the Coorong, were captured during the warmer months, while both the size and age ranges estimated from otoliths at the Long Point site were slightly broader (337-1265 mm TL and 3-19 years; Disspain and others 2011) than those at Greenfields. Given the similarities between the two archaeological sites, it is probable that technologies and fishing methods were similar or perhaps shared between the two groups, the Ngarrindjeri and the Kaurna, who, in early historical times, were reported to meet regularly to trade various commodities (Berndt and others 1993). Historical records detail fishing techniques used by the Kaurna; netting was a commonly used technique (Campbell 1979), and nets have been excavated from a cave further south along the coast (Tindale and Mountford 1936). Spearfishing was also used during historical times (Hemming 1985), while the use of hook and line is questioned (Radford and Campbell 1982). The Ngarrindjeri of the Coorong and Lower Lakes region utilised an extensive array of technologies and techniques to harvest fish, including hooks (Gerritsen 2001), netting and baskets, spearing from canoes and watercraft (Berndt and others 1993; Clarke 2002), and the construction and use of intricate fish traps, some of which still exist today (Ross 2009).

Fishing technologies used to harvest $A$. japonicus during the three time spans compared here would have been vastly different. The mulloway from the archaeological site may have been captured using any of the above mentioned methods; the large size and predatory nature of adult mulloway makes it an ideal target for spearing or hook and line methods, while the schooling nature of juveniles means that nets would also be an ideal catch method. During historical times, the increasing European population developed technologies for mass capture and storage (such as freezing fish), which enabled greater distances to be travelled and larger catches to be harvested and stored (Pitcher and Lam 2015). These advances, along with the exploration of new fishing grounds and somewhat inadequate fisheries regulation, means that historical data represent efforts beyond the capabilities of Indigenous people prior to European settlement of the region. Modern fisheries data represent possibly a more well-regulated and enforced fisheries industry with technologies that enable even more significant distances to be travelled and specific size or species of fish to be targeted. As such, the data presented here corresponds to different eras in the development of fishing in eastern South Australia, and are influenced by the associated technologies. Despite this, the data provide snapshots of $A$. japonicus populations that would otherwise be unobtainable. Global species with similar vulnerabilities to $A$. japonicus, such as snapper (Pagrus auratus) in New Zealand (Parsons and others 2009) or gadids in the northern hemisphere (Maschner and others 2008; Ólafsdóttir and others 2017; Van Neer and others 2002) may benefit from a similar approach to that used in this study. 


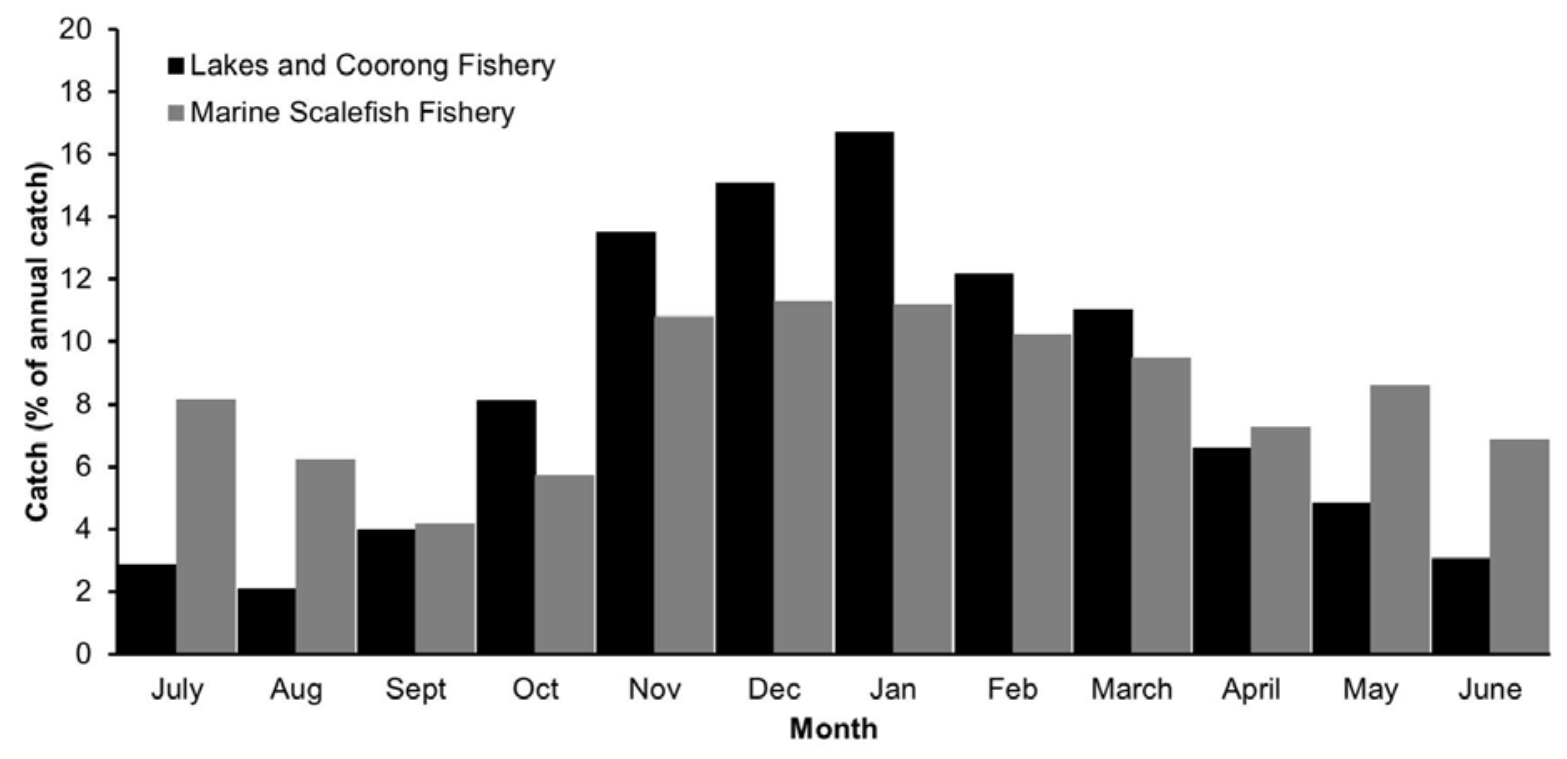

Figure 5. Average monthly catches of mulloway from the LCF and MSF from 1984/1985 to 2013/2014, expressed as a percentage of annual catch. Compiled from modern fisheries data (Earl and Ward 2014)

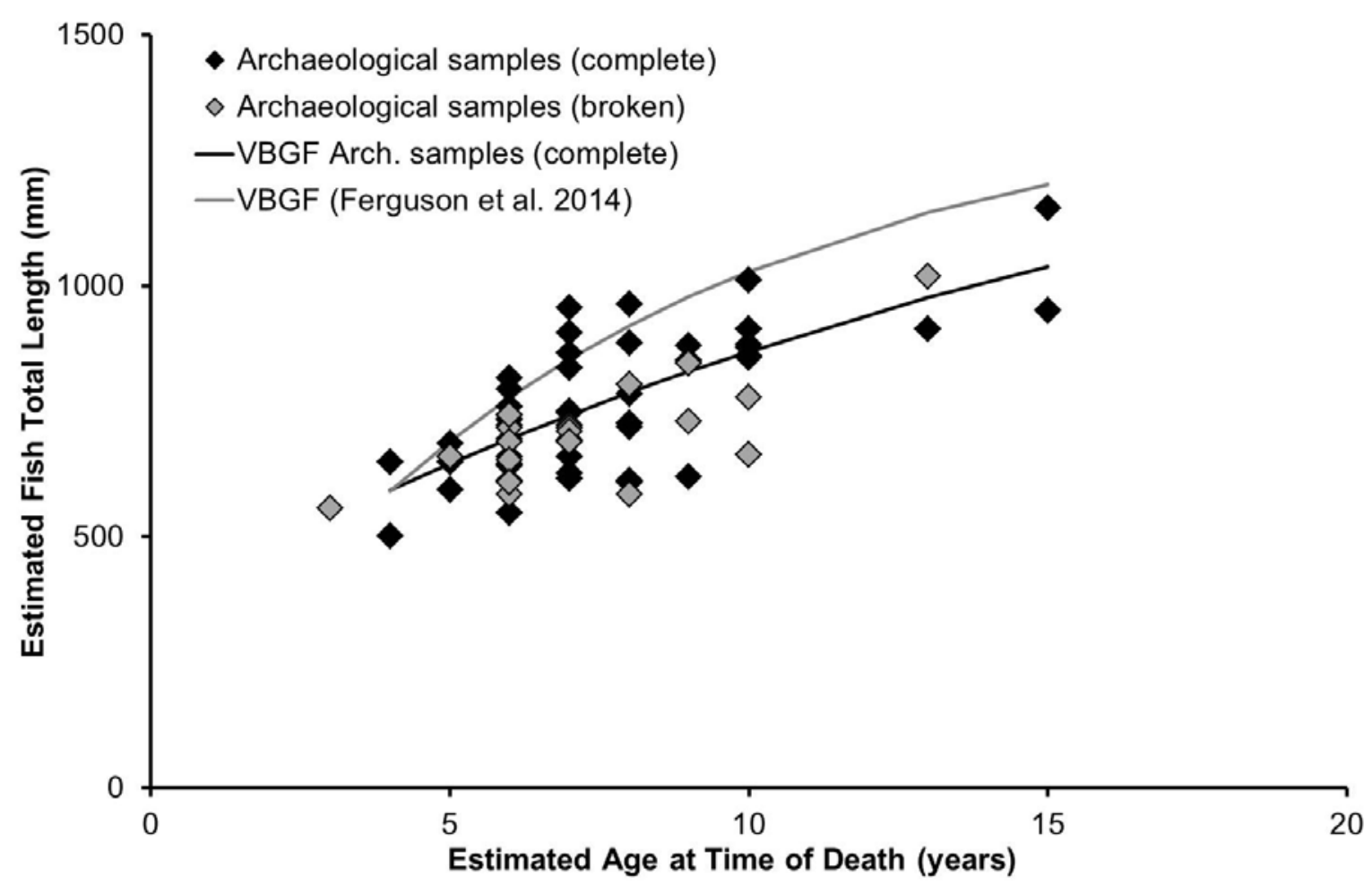

Figure 6. Von Bertalanffy growth function fitted to age-length data for complete archaeological samples from Greenfields, South Australia, compared with Von Bertalanffy growth function using parametres of modern Argyrosomus japonicus (male, female, and unsexed) from eastern South Australia (Ferguson et al. 2014). 


\section{Conclusions}

Evaluation and comparison of three sequential eras of mulloway fishing along the eastern coast of South Australia have revealed only minor differences in size, age and growth of the species over the timespan. While the data indicate size continuity from prehistoric times through to the modern day, they must be interpreted with caution, owing to the differences among available sources of data. The historical anecdotes are filled with mentions of the boundless availability of giant fish, and while these may be exaggerations and 'fishermen's tales' it is in stark contrast to the current state of the fishery, with catch rates at the lowest recorded level, attributed to a decline in targeted fishing effort (Earl and Ward 2014). Interestingly, no significant changes in the maximum size of mulloway were indicated throughout the historical period. While this study did not highlight a significant change in fish age or size through time, it did demonstrate the benefit of combining datasets from extended periods to examine fish dynamics over thousands of years.

\section{Acknowledgements}

This research was conducted with the support of the Australian Institute of Aboriginal and Torres Strait Islander Studies (G2011/7636 awarded to BMG and MD). The authors wish to thank AINSE Ltd for providing financial assistance (ALNGRA11014 awarded to BMG and MD) to enable radiocarbon dating of five otolith samples to be conducted, and Greg Ferguson at SARDI who assisted with the ageing and growth determination for the archaeological mulloway. BMG acknowledges funding from the Australian Research Council through an ARC Future Fellowship (FT100100767) and an ARC Discovery project (DP110100716). SU is the recipient of an Australian Research Council Future Fellowship (FT120100656). Work on this paper was undertaken while SU was visiting as an Honorary Fellow in the School of Social Sciences, The University of Western Australia.

\section{References}

Alleway, H.K.; Gillanders, B.M.; Connell, S.D. 'Neo Europe' and its ecological consequences: the example of systematic degradation in Australia's inland fisheries. Biology Letters. 12; 2016

Barnes, T.C.; Gillanders, B.M. Population Structure of the Mulloway (Argyrosomus japonicus) in South Australia. South Australian Naturalist, The. 85:21-25; 2011

Berkeley, S.A.; Hixon, M.A.; Larson, R.J.; Love, M.S. Fisheries Sustainability via Protection of Age Structure and Spatial Distribution of Fish Populations. Fisheries. 29:23-32; 2004

Berndt, R.M.; Berndt, C.H.; Stanton, J.E. The World That was: The Yaraldi of the Murray River and the Lakes, South Australia. Vancouver: UBC Press; 1993

Butler, V.L. Seeking Balance in "Human Impacts" Research. Comment on Julio Baisre's "Setting a Baseline for Caribbean Fisheries". The Journal of Island and Coastal Archaeology. 5:148-151;2010

Campbell, V. Archaeological reconstruction of coastal sites south of Adelaide. Journal of the Anthropological Society of South Australia. 17:1-10; 1979

Carder, N.; Crock, J.G. A pre-Columbian fisheries baseline from the Caribbean. Journal of Archaeological Science. 39:3115-3124; 2012

Casteel, R.W. Fish Remains in Archaeology and Palaeo-environmental Studies. London: Academic Press Ltd; 1976 
Clarke, P.A. Early Aboriginal fishing technology in the Lower Murray, South Australia. Records of the South Australian Museum. 35:147-167; 2002

Disspain, M.; Wallis, L.A.; Gillanders, B.M. Developing baseline data to understand environmental change: a geochemical study of archaeological otoliths from the Coorong, South Australia. Journal of Archaeological Science. 38:1842-1857; 2011

Disspain, M.C.F.; Ulm, S.; Gillanders, B.M. Otoliths in archaeology: Methods, applications and future prospects. Journal of Archaeological Science: Reports. 6:623-632; 2016

Disspain, M.C.F.; Wallis, L.A.; Fallon, S.J.; Sumner, M.; St George, C.; Wilson, C.; Wright, D.; Gillanders, B.M.; Ulm, S. Direct radiocarbon dating of fish otoliths from mulloway (Argyrosomus japonicus) and black bream (Acanthopagrus butcheri) from Long Point, Coorong, South Australia. Journal of the Anthropological Society of South Australia. 41:3-17; 2017

Earl, J.; Ward, T.M. Mulloway (Argyrosomus japonicus) Stock Assessment Report 2013/2014. Report to PIRSA Fisheries and Aquaculture Adelaide: South Australian Research and Development Institute (Aquatic Sciences); 2014

Fallon, S.J.; Fifield, L.K.; Chappell, J.M. The next chapter in radiocarbon dating at The Australian National University: status report on the single stage AMS. Nuclear Instruments and Methods in Physics Research Section B: Beam Interactions with Materials and Atoms. 268:898-901; 2010

Farmer, B.M. Comparisons of the biological and genetic characteristics of the Mulloway Argyrosomus japonicus (Sciaenidae) in different regions of Western Australia. Western Australia: Murdoch University; 2008

Ferguson, G.; Ward, T. Mulloway (Argyrosomus japonicus) Fishery: Fishery Assesment Report to the PIRSA Fisheries for the Inland Waters and Marine Scalefish Fishery Managment Committees. Adelaide: SARDI Aquatic Sciences; 2003

Ferguson, G.J.; Ward, T.M.; Geddes, M.C. Do recent age structures and historical catches of mulloway, Argyrosomus japonicus (Sciaenidae), reflect freshwater inflows in the remnant estuary of the Murray River, South Australia? Aquatic Living Resources. 21:145-152; 2008

Ferguson, G.J.; Ward, T.M.; Gillanders, B.M. Otolith shape and elemental composition: Complementary tools for stock discrimination of mulloway (Argyrosomus japonicus) in southern Australia. Fisheries Research. 110:75-83; 2011

Ferguson, G.J.; Ward, T.M.; Ivey, A.; Barnes, T. Life history of Argyrosomus 643 japonicus, a large sciaenid at the southern part of its global distribution: implications for fisheries management. Fisheries Research. 151:148-157; 2014

Fink, D.; Hotchkis, M.; Hua, Q.; Jacobsen, G.; Smith, A.M.; Zoppi, U.; Child, D.; Mifsud, C.; van der Gaast, H.; Williams, A.; Williams, M. The ANTARES AMS facility at ANSTO. Nuclear Instruments and Methods in Physics Research Section B: Beam Interactions with Materials and Atoms. 223-224:109-115; 2004

Flood, M.; Stobutzki, I.; Andrews, J.; Ashby, C.; Begg, G.A.; Fletcher, R.; Gardner, C.A.; Georgeson, L.; Hansen, S.; Hartmann, K.; Hone, P.; Horvat, P.; Maloney, L.; McDonald, B.; Moore, A.; Roelofs, A.; Sainsbury, K.; Saunders, T.; Smith, T.; Stewardson, C.; Stewart, J.; Wise, B. Status of key Australian fish stocks reports 2014. Canberra: Fisheries Research and Development Corporation; 2014 
Fowler, A.; Ling, J. Ageing studies done 50 years apart for an inshore fish species from southern Australia contribution towards determining current stock status. Environmental Biology of Fishes. 89:253-265; 2010

Galik, A.; Haidvogl, G.; Bartosiewicz, L.; Guti, G.; Jungwirth, M. Fish remains as a source to reconstruct long-term changes of fish communities in the Austrian and Hungarian Danube. Aquatic Sciences. 77:337$354 ; 2015$

Gerritsen, R. Aboriginal Fish Hooks in Southern Australia: Evidence, Arguments and Implications. Australian Archaeology:18-28; 2001

Gillanders, B.M.; Elsdon, T.S.; Hammer, M. Chapter 14. Estuaries of Gulf St Vincent, Investigator Strait, and Backstairs Passage. in: Shepherd S., Australia R.S.o.S., eds. The Natural History of Gulf St Vincent. Adelaide: Royal Society of South Australia; 2008

Giri, K.; Hall, K. South Australian Recreational Fishing Survey. Fisheries Victoria Internal Report Series; 2015

Griffiths, M.H. Life history of the dusky kob Argyrosomus japonicus (Sciaenidae) off the east coast of South Africa. South African Journal of Marine Science. 17:135-154; 1996

Griffiths, M.H.; Hecht, T. Age and growth of South African dusky kob Argyrosomus japonicas (Sciaenidae) based on otoliths. South African Journal of Marine Science. 16:119-128; 1995

Haidvogl, G.; Hoffmann, R.; Pont, D.; Jungwirth, M.; Winiwarter, V. Historical ecology of riverine fish in Europe. Aquatic Sciences. 77:315-324; 2015

Hemming, S. Aboriginies of Port Willunga: Reminicences of Thomas Martin. Journal of the Anthropological Society of South Australia. 23:24-28; 1985

Hobday, A.J. Sliding baselines and shuffling species: implications of climate change for marine conservation. Marine Ecology. 32:392-403; 2011

Hua, Q.; Jacobsen, G.; Zoppi, U.; Lawson, E.; Williams, A.; McGann, M. Progress in radiocarbon target preparation at the ANTARES AMS Centre. Radiocarbon. 43:275-282; 2001

Izzo, C.; Doubleday, Z.A.; Grammer, G.L.; Gilmore, K.L.; Alleway, H.K.; Barnes, T.C.; Disspain, M.C.F.; Giraldo, A.J.; Mazloumi, N.; Gillanders, B.M. Fish as proxies of ecological and environmental change. Reviews in Fish Biology and Fisheries:1-22; 2016

Jackson, G.; Jones, G.K. Spatial and temporal variation in nearshore fish and macroinvertebrate assemblages from a temperate Australian estuary over a decade. Marine Ecology Progress Series. 182:253-268; 1999

Jones, G.; Baker, J.; Edyvane, K.; Wright, G. Nearshore fish community of the Port River-Barker Inlet Estuary, South Australia. I. Effect of thermal effluent on the fish community structure, and distribution and growth of economically important fish species. Marine and Freshwater Research. 47:785-799; 1996

Jones, K.; Doonan, A.M. 2000-2001 National Recreational and Indigenous Fishing Survey: South Australian Regional Information. Report no. 46. Adelaide; 2005

Jones, T.L.; Gobalet, K.W.; Codding, B.F. The archaeology of fish and 692 fishing on the central coast of California: The case for an under-exploited resource. Journal of Anthropological Archaeology. 41:88-108; 2016 
Klaer, N.L. Steam trawl catches from south-eastern Australia from 1918 to 1957: trends in catch rates and species composition. Marine and Freshwater Research. 52:399-410; 2001

Limburg, K.E.; Walther, Y.; Hong, B.; Olson, C.; Stora, J. Prehistoric versus modern Baltic Sea cod fisheries: selectivity across the millennia. Proceedings of the Royal Society B: Biological Sciences. 275:2659-2665; 2008

Mannino, M.A.; Thomas, K.D. Depletion of a resource? The impact of prehistoric human foraging on intertidal mollusc communities and its significance for human settlement, mobility and dispersal. World Archaeology. 33:452-474; 2002

Maschner, H.D.G.; Betts, M.W.; Reedy-Maschner, K.L.; Trites, A.W. A 4500-year time series of Pacific cod (Gadus macrocephalus) size and abundance: archaeology, oceanic regime shifts, and sustainable fisheries. Fishery Bulletin. 106:386+; 2008

Ólafsdóttir, G.Á.; Pétursdóttir, G.; Bárðarson, H.; Edvardsson, R. A millennium of north-east Atlantic cod juvenile growth trajectories inferred from archaeological otoliths. PLoS One. 12; 2017

Papworth, S.K.; Rist, J.; Coad, L.; Milner-Gulland, E.J. Evidence for shifting baseline syndrome in conservation. Conservation Letters. 2:93-100; 2009

Parsons, D.M.; Morrison, M.A.; MacDiarmid, A.B.; Stirling, B.; Cleaver, P.; Smith, I.W.G.; Butcher, M. Risks of shifting baselines highlighted by anecdotal accounts of New Zealand's snapper (Pagrus auratus) fishery. New Zealand Journal of Marine and Freshwater Research. 43:965-983; 2009

Pauly, D. Anecdotes and the shifting baseline syndrome of fisheries. Trends in Ecology \& Evolution. 10:430; 1995

PIRSA. Fishing Limits: Mulloway. 2015

Pitcher, T.J.; Lam, M.E. Fish commoditization and the historical origins of catching fish for profit. Maritime Studies. 14:1-19; 2015

Radford, R.; Campbell, V. Archaeology of the southern Adelaide region: Part 4 material culture. Journal of the Anthropological Society of South Australia. 20:1-8; 1982

Reimer, P.J.; Bard, E.; Bayliss, A.; Beck, J.W.; Blackwell, P.G.; Bronk Ramsey, C.; Buck, C.E.; Cheng, H.; Edwards, R.L.; Friedrich, M.; Grootes, P.M.; Guilderson, T.P.; Haflidason, H.; Hajdas, I.; Hatté, C.; Heaton, T.J.; Hogg, A.G.; Hughen, K.A.; Kaiser, K.F.; Kromer, B.; Manning, S.W.; Niu, M.; Reimer, R.W.;

Richards, D.A.; Scott, E.M.; Southon, J.R.; Turney, C.S.M.; van der Plicht, J. IntCal13 and MARINE13 radiocarbon age calibration curves 0-50,000 years cal. BP. Radiocarbon. 55:1869-1887; 2013

Reitz, E.J. "Fishing down the Food Web": A Case Study from St. Augustine, Florida, USA. American Antiquity. 69:63-83; 2004

Rosenberg, A.A.; Bolster, W.J.; Alexander, K.E.; Leavenworth, W.B.; Cooper, A.B.; McKenzie, M.G. The history of ocean resources: modeling cod biomass using historical records. Frontiers in Ecology and the Environment. 3:84-90; 2005

Ross, P.J. Ngarrindjeri Fish Traps of the Lower Murray Lakes and Northern Coorong Estuary, South Australia. Archaeology Department, School of Humanities. South Australia: Flinders University; 2009 
Rowell, K.; Flessa, K.; Dettman, D.L.; Roman, M. The importance of Colorado River flow to nursery habitats of the Gulf corvina (Cynoscion othonopterus). Canadian Journal of Fisheries and Aquatic Science. 62:2874-2885; 2005

Rowell, K.; Flessa, K.; Dettman, D.L.; Roman, M.; Gerber, L.R.; Findley, L.T. Diverting the Colorado River leads to a dramatic life history shift in an endangered marine fish. Biological Conservation. 141:1138-1148; 2008

Schaerlaekens, D.G.; Dekker, W.; Wickström, H.; Volckaert, F.A.M.; Maes, 741 G.E. Extracting a century of preserved molecular and population demographic data from archived otoliths in the endangered European eel (Anguilla anguilla L.). Journal of Experimental Marine Biology and Ecology. 398:56-62; 2011

Scott, T.D.; Glover, C.J.M.; Southcott, R.V. The Marine and Freshwater Fishes of South Australia. Adelaide: A.B. James, Government Printer; 1974

Selleslagh, J.; Echard, A.; Pécheyran, C.; Baudrimont, M.; Lobry, J.; Daverat, F. Can analysis of 748 Platichthys flesus otoliths provide relevant data on historical metal pollution in estuaries? 749 Experimental and in situ approaches. Science of The Total Environment. 557-558:20-30; 2016

Silberschneider, V.; Gray, C.A. Synopsis of biological, fisheries and aquaculture-related information on mulloway Argyrosomus japonicus (Pisces: Sciaenidae), with particular reference to Australia. Journal of Applied Ichthyology. 24:7-17; 2008

Silberschneider, V.; Gray, C.A.; Stewart, J. Age, growth, maturity and the overfishing of the iconic sciaenid, Argyrosomus japonicus, in south-eastern, Australia. Fisheries Research. 95:220-229; 2009

Stuiver, M.; Polach, H.A. Discussion: reporting of 14C data. Radiocarbon. 19:355-363; 1977

Stuiver, M.; Reimer, P.J. Extended 14C database and revised CALIB radiocarbon calibration program. Radiocarbon. 35:215-230; 1993

Thomas, B.P. Coastal acid sulfate soil processes in Barker Inlet, South Australia. School of Earth and Environmental Sciences: The University of Adelaide; 2010

Thurstan, R.H.; Campbell, A.B.; Pandolfi, J.M. Nineteenth century narratives reveal historic catch rates for Australian snapper (Pagrus auratus). Fish and Fisheries. 17:210-225; 2016

Thurstan, R.H.; McClenachan, L.; Crowder, L.B.; Drew, J.A.; Kittinger, J.N.; Levin, P.S.; Roberts, C.M.; Pandolfi, J.M. Filling historical data gaps to foster solutions in marine conservation. Ocean and Coastal Management. 115:31-40; 2015

Tindale, N.B.; Mountford, C.P. Results of the excavation of Kongarati Cave, near Second Valley, South Australia. Records of the South Australian Museum. 5:487-502; 1936

Ulm, S. Australian Marine Reservoir Effects: A Guide to $\Delta$ R Values. Australian Archaeology. 63:57-60; 2006

Van Neer, W.; Ervynck, A.; Bolle, L.J.; Millner, R.S.; Rijnsdorp, A.D. Fish otoliths and their relevance to archaeology: an analysis of medieval, post-medieval and recent material of plaice, cod and haddock from the North Sea. Environmental Archaeology. 7:65-81; 2002 